Original Research Article

\title{
Assessment of oral hypoglycaemic activity of water soluble extract of aloe vera and its interaction with glipizide in alloxan induced diabetic Wistar Rats
}

\author{
Vikalp Tiwari, Gopal Gudsurkar*
}

Department of Pharmacology, M.G.M. Medical College, Indore, Madhya Pradesh, India

Received: 30 June 2017 Accepted: 05 July 2017

*Correspondence to: Dr. Gopal Gudsurkar, Email: drgopalofficial@ gmail.com

Copyright: (C) the author(s), publisher and licensee Medip Academy. This is an openaccess article distributed under the terms of the Creative Commons Attribution NonCommercial License, which permits unrestricted noncommercial use, distribution, and reproduction in any medium, provided the original work is properly cited.

\begin{abstract}
Background: Assessment of oral hypoglycaemic activity of water soluble extract of Aloe vera and its interaction with Glipizide in Alloxan induced diabetic Wistar rats.

Methods: Under standard condition of testing, alloxan induced diabetic rats were kept in fasting state of 8 hours and then glucose in dose of $1 \mathrm{gm} / \mathrm{kg}$ was given PO by feeding tube. There after water soluble extract of aloe vera in dose of $200 \mathrm{mg} / \mathrm{kg}$ BW dissolves in $1 \mathrm{ml}$ of Distilled water (DW) to test group 1, Glipizide in dose of $2.5 \mathrm{mg} / \mathrm{kg} \mathrm{BW}$ dissolved in $1 \mathrm{ml} \mathrm{DW}$ was given to standard group. Test group 2 received combination of Aloe vera $200 \mathrm{mg} / \mathrm{kg}$ BW and Glipizide in dose of $2.5 \mathrm{mg} / \mathrm{kg} \mathrm{BW}$ dissolved in $1 \mathrm{ml} \mathrm{Dw}$. Control group received $1 \mathrm{ml}$ of Distilled water. Blood sugars levels of all Rats in each group were checked with Glucometer.

Results: Clinically and statistically significant glucose lowering effect was observed in groups administered with Aloe vera and better results were observed in group receiving Aloe vera and Glipizide combination.

Conclusions: Water soluble extract of aloe vera has significant hypoglycaemic activity and the results showed that co-administration of Aloe vera and Glipizide has superior hypoglycaemic activity compared to Aloe vera and Glipizide given Individually.
\end{abstract}

Keywords: Alloxan, Aloe vera, Glipizide, Hypoglycaemia

\section{INTRODUCTION}

According to the World Health Organization, India had 69.2 million people living with diabetes $(8.7 \%)$ as per the 2015 data, of these, it remained undiagnosed in more than 36 million people. ${ }^{1}$ India is witnessing a silent epidemic of this non communicable life style menace. It is worth noted that there has been a plethora of therapeutic options for Diabetes mellitus. India being the land of Ayurveda, has ancient history of use of medicinal plants for treatment of various diseases like constipation, Osteoarthritis, cancer, wound healing, burns, skin diseases etc. ${ }^{2}$ Patients have the growing tendency to self-treat themselves with herbal drugs along with prescribed allopathic medicines. For
Diabetes in particular, market is studded with many herbal products.

One of the popular herbal drugs considered medicinal plant in Ayurveda is Aloe Vera. There have been scientific evidences of the use of Aloe Vera as an anti-diabetic agent. $^{3}$

Considering the low cost, ease of availability and literature support in favour of Aloe Vera, the present study was conducted to assess the effect of water soluble extract of aloe vera and effect of aloe vera and Glipizide given concomitantly on glucose metabolism in Alloxan induced diabetic Rats. 


\section{METHODS}

Albino Wistar rats of up to 230 -250grams were taken and injected $150 \mathrm{mg} / \mathrm{kg}$ of Alloxan ip and kept in standard experimental conditions for 3 days. ${ }^{4}$ The rats were free to move in their cages. Food, water was available ad-libitum. 12 hours light and dark cycle was ensured with temperature maintained at 25 degree centigrade. OECD guidelines were considered for testing of animals with drugs and LD50 was determined. ${ }^{5}$ The rats were kept in fasting state for 3 hours prior to study and were given single dose of Water soluble extract of Aloe vera and were observed for its mortality up to 48 hours. From the LD50 dose $1 / 5^{\text {th }}$ and $1 / 10^{\text {th }}$ doses were selected as safe doses and used in acute short term study.

Aloe vera barbedesis was collected from garden of MGM Medical college Indore and was identified by botanist. Wistar Rats of 230 to 250 grams were taken and induced diabetes Rats with a cut of value of fasting blood sugar level of more than $200 \mathrm{mg} / \mathrm{dl}$ in rats were considered diabetic and used during experiment.

\section{Preparation of water soluble extract of Aloe vera}

Aloe vera leaves were processed by removing the outer coat and the pulp obtained was kept in shade for drying. The dried pulp was powdered and dissolved in chloroform and filtered through filter paper. The supernatant left in the filter paper was dried and later dissolved in water and separated by filter paper. The water-soluble extract so obtained was dried and stored in air tight bottles for experimental use.

Rats were made to remain in fasting state 8 hours prior to experiment. Then Rats were divided in four groups. Each group had 8 rats. Each rat was fed with glucose in dose of $1 \mathrm{gm} / \mathrm{kg}$ of body weight. Then experiment was conducted in which Group 1 (control) was fed with $1 \mathrm{ml}$ Distilled water (DW) via feeding tube. Group 2 (standard) received Glipizide in the dose of $2.5 \mathrm{mg} / \mathrm{kg} \mathrm{BWpo.} \mathrm{Group} 3$ (test 1 ) received Aloe vera in dose of $200 \mathrm{mg} / \mathrm{kg} \mathrm{BW}$ po. ${ }^{6}$ Group 4 (test 2) received both Aloe vera $200 \mathrm{mg} / \mathrm{kg} \mathrm{BW} \mathrm{PO}$ and $2.5 \mathrm{mg} / \mathrm{kg}$ BW PO of Glipizide.

Blood samples were collected from tail vein of rats and glucose estimation was done using Glucotrend II Glucometer made by Nicholas USA at the interval of 1hour, 2hours and 3hours. ${ }^{7}$

\section{RESULTS}

In all the groups the blood glucose levels were measured 4 times in the Alloxan induced diabetic Wistar Rats.

- Pre-test glucose levels

- 1 hour after administration of the group specific agent

- 2 hours after administration of the group specific agent

- 3 hours after administration of the group specific agent
Since there were four groups, in the first group (Control) the effect was recorded after administration of $1 \mathrm{ml}$. of Distilled water (DW) (Table 1).

\section{Table 1: Group 1 control - effect on administration of} $1 \mathrm{ml}$ of $\mathrm{DW}^{*}$.

\begin{tabular}{|llll|}
\hline $\begin{array}{l}\text { Pre test } \\
\text { blood } \\
\text { glucose } \\
\text { levels }\end{array}$ & $\begin{array}{l}\text { Blood } \\
\text { glucose } \\
\text { level at 1 } \\
\text { hour }\end{array}$ & $\begin{array}{l}\text { Blood } \\
\text { glucose } \\
\text { level at } 2 \\
\text { hours }\end{array}$ & $\begin{array}{l}\text { Blood } \\
\text { glucose level } \\
\text { at } 3 \text { hours }\end{array}$ \\
\hline $388 \mathrm{mg} / \mathrm{dl}$ & $374 \mathrm{mg} / \mathrm{dl}$ & $350 \mathrm{mg} / \mathrm{dl}$ & $343 \mathrm{mg} / \mathrm{dl}$ \\
\hline $442 \mathrm{mg} / \mathrm{dl}$ & $422 \mathrm{mg} / \mathrm{dl}$ & $390 \mathrm{mg} / \mathrm{dl}$ & $375 \mathrm{mg} / \mathrm{dl}$ \\
\hline $390 \mathrm{mg} / \mathrm{dl}$ & $364 \mathrm{mg} / \mathrm{dl}$ & $347 \mathrm{mg} / \mathrm{dl}$ & $336 \mathrm{mg} / \mathrm{dl}$ \\
\hline $392 \mathrm{mg} / \mathrm{dl}$ & $367 \mathrm{mg} / \mathrm{dl}$ & $351 \mathrm{mg} / \mathrm{dl}$ & $340 \mathrm{mg} / \mathrm{dl}$ \\
\hline $426 \mathrm{mg} / \mathrm{dl}$ & $402 \mathrm{mg} / \mathrm{dl}$ & $381 \mathrm{mg} / \mathrm{dl}$ & $368 \mathrm{mg} / \mathrm{dl}$ \\
\hline $371 \mathrm{mg} / \mathrm{dl}$ & $359 \mathrm{mg} / \mathrm{dl}$ & $326 \mathrm{mg} / \mathrm{dl}$ & $316 \mathrm{mg} / \mathrm{dl}$ \\
\hline $370 \mathrm{mg} / \mathrm{dl}$ & $368 \mathrm{mg} / \mathrm{dl}$ & $350 \mathrm{mg} / \mathrm{dl}$ & $328 \mathrm{mg} / \mathrm{dl}$ \\
\hline $404 \mathrm{mg} / \mathrm{dl}$ & $396 \mathrm{mg} / \mathrm{dl}$ & $382 \mathrm{mg} / \mathrm{dl}$ & $361 \mathrm{mg} / \mathrm{dl}$ \\
\hline
\end{tabular}

${ }^{*}$ Rats were made to remain in fasting state 8 hours prior to experiment; Blood glucose levels were monitored at 1 hours, 2 hours and 3 hours

In Group 2 the effect was observed after administration of Glipizide $2.5 \mathrm{mg} / \mathrm{kg}$ Body Weight (BW).

The blood glucose levels were measured in similar fashion as mentioned above (Table 2).

Table 2: Group 2 - effect on administration of glipizide $2.5 \mathrm{mg} / \mathrm{kg} \mathrm{BW}$.

\begin{tabular}{|llll|}
\hline $\begin{array}{l}\text { Pre test } \\
\text { blood } \\
\text { glucose } \\
\text { levels }\end{array}$ & $\begin{array}{l}\text { Blood } \\
\text { glucose } \\
\text { level at } \\
\text { 1hour }\end{array}$ & $\begin{array}{l}\text { Blood } \\
\text { glucose } \\
\text { level at 2 } \\
\text { hours }\end{array}$ & $\begin{array}{l}\text { Blood } \\
\text { glucose } \\
\text { level at 3 } \\
\text { hours }\end{array}$ \\
\hline $447 \mathrm{mg} / \mathrm{dl}$ & $363 \mathrm{mg} / \mathrm{dl}$ & $202 \mathrm{mg} / \mathrm{dl}$ & $107 \mathrm{mg} / \mathrm{dl}$ \\
\hline $398 \mathrm{mg} / \mathrm{dl}$ & $288 \mathrm{mg} / \mathrm{dl}$ & $165 \mathrm{mg} / \mathrm{dl}$ & $101 \mathrm{mg} / \mathrm{dl}$ \\
\hline $387 \mathrm{mg} / \mathrm{dl}$ & $269 \mathrm{mg} / \mathrm{dl}$ & $154 \mathrm{mg} / \mathrm{dl}$ & $87 \mathrm{mg} / \mathrm{dl}$ \\
\hline $380 \mathrm{mg} / \mathrm{dl}$ & $270 \mathrm{mg} / \mathrm{dl}$ & $210 \mathrm{mg} / \mathrm{dl}$ & $128 \mathrm{mg} / \mathrm{dl}$ \\
\hline $357 \mathrm{mg} / \mathrm{dl}$ & $270 \mathrm{mg} / \mathrm{dl}$ & $166 \mathrm{mg} / \mathrm{dl}$ & $100 \mathrm{mg} / \mathrm{dl}$ \\
\hline $374 \mathrm{mg} / \mathrm{dl}$ & $289 \mathrm{mg} / \mathrm{dl}$ & $199 \mathrm{mg} / \mathrm{dl}$ & $123 \mathrm{mg} / \mathrm{dl}$ \\
\hline $393 \mathrm{mg} / \mathrm{dl}$ & $317 \mathrm{mg} / \mathrm{dl}$ & $227 \mathrm{mg} / \mathrm{dl}$ & $158 \mathrm{mg} / \mathrm{dl}$ \\
\hline $402 \mathrm{mg} / \mathrm{dl}$ & $312 \mathrm{mg} / \mathrm{dl}$ & $216 \mathrm{mg} / \mathrm{dl}$ & $155 \mathrm{mg} / \mathrm{dl}$ \\
\hline
\end{tabular}

* Rats were made to remain in fasting state 8 hours prior to experiment; Blood glucose levels were monitored at 1 hours, 2 hours and 3 hours

In Group 3 the effect was observed after administration of test 1 - Aloevera $200 \mathrm{mg} / \mathrm{kg} \mathrm{BW}$.

The blood glucose levels were measured in similar fashion as mentioned above (Table 3 ).

In Group 4 the effect was observed after administration of test 2- Aloevera $200 \mathrm{mg} / \mathrm{kg} \mathrm{BW}+$ Glipizide $2.5 \mathrm{mg} / \mathrm{kg} \mathrm{BW}$.

The blood glucose levels were measured in similar fashion as mentioned above (Table 4). 
Table 3: Group 3 - effect on administration of test 1Aloevera 200mg/kg BW.

\begin{tabular}{|llll|}
\hline $\begin{array}{l}\text { Pre test } \\
\text { blood } \\
\text { glucose } \\
\text { levels }\end{array}$ & $\begin{array}{l}\text { Blood } \\
\text { glucose } \\
\text { level at } \\
\text { 1hour }\end{array}$ & $\begin{array}{l}\text { Blood } \\
\text { glucose } \\
\text { level at 2 } \\
\text { hours }\end{array}$ & $\begin{array}{l}\text { Blood } \\
\text { glucose } \\
\text { level at 3 } \\
\text { hours }\end{array}$ \\
\hline $382 \mathrm{mg} / \mathrm{dl}$ & $260 \mathrm{mg} / \mathrm{dl}$ & $146 \mathrm{mg} / \mathrm{dl}$ & $98 \mathrm{mg} / \mathrm{dl}$ \\
\hline $390 \mathrm{mg} / \mathrm{dl}$ & $280 \mathrm{mg} / \mathrm{dl}$ & $151 \mathrm{mg} / \mathrm{dl}$ & $104 \mathrm{mg} / \mathrm{dl}$ \\
\hline $363 \mathrm{mg} / \mathrm{dl}$ & $256 \mathrm{mg} / \mathrm{dl}$ & $138 \mathrm{mg} / \mathrm{dl}$ & $87 \mathrm{mg} / \mathrm{dl}$ \\
\hline $400 \mathrm{mg} / \mathrm{dl}$ & $285 \mathrm{mg} / \mathrm{dl}$ & $140 \mathrm{mg} / \mathrm{dl}$ & $106 \mathrm{mg} / \mathrm{dl}$ \\
\hline $394 \mathrm{mg} / \mathrm{dl}$ & $270 \mathrm{mg} / \mathrm{dl}$ & $146 \mathrm{mg} / \mathrm{dl}$ & $90 \mathrm{mg} / \mathrm{dl}$ \\
\hline $386 \mathrm{mg} / \mathrm{dl}$ & $251 \mathrm{mg} / \mathrm{dl}$ & $121 \mathrm{mg} / \mathrm{dl}$ & $74 \mathrm{mg} / \mathrm{dl}$ \\
\hline $441 \mathrm{mg} / \mathrm{dl}$ & $282 \mathrm{mg} / \mathrm{dl}$ & $159 \mathrm{mg} / \mathrm{dl}$ & $101 \mathrm{mg} / \mathrm{dl}$ \\
\hline $426 \mathrm{mg} / \mathrm{dl}$ & $257 \mathrm{mg} / \mathrm{dl}$ & $143 \mathrm{mg} / \mathrm{dl}$ & $70 \mathrm{mg} / \mathrm{dl}$ \\
\hline
\end{tabular}

* Rats were made to remain in fasting state 8 hours prior to experiment; Blood glucose levels were monitored at 1 hours, 2 hours and 3 hours

Table 4: Group 4 - effect on administration of test 2Aloevera $200 \mathrm{mg} / \mathrm{kgBW}+$ Glipizide $2.5 \mathrm{mg} / \mathrm{kg}$ BW.

\begin{tabular}{|llll|}
\hline $\begin{array}{l}\text { Pre test } \\
\text { blood } \\
\text { glucose } \\
\text { levels }\end{array}$ & $\begin{array}{l}\text { Blood } \\
\text { glucose } \\
\text { level at } \mathbf{1} \\
\text { hour }\end{array}$ & $\begin{array}{l}\text { Blood } \\
\text { glucose } \\
\text { level at } 2 \\
\text { hours }\end{array}$ & $\begin{array}{l}\text { Blood } \\
\text { glucose } \\
\text { level at } 3 \\
\text { hours }\end{array}$ \\
\hline 411 & 216 & 118 & 62 \\
\hline 438 & 200 & 100 & 70 \\
\hline 395 & 196 & 119 & 58 \\
\hline 379 & 177 & 106 & 71 \\
\hline 418 & 198 & 92 & 53 \\
\hline 390 & 188 & 117 & 75 \\
\hline 399 & 202 & 116 & 66 \\
\hline 380 & 165 & 101 & 52 \\
\hline
\end{tabular}

${ }^{*}$ Rats were made to remain in fasting state 8 hours prior to experiment; Blood glucose levels were monitored at 1 hours, 2 hours and 3 hours

The glucose lowering effect of the group 4 (combined Aloevera $200 \mathrm{mg} / \mathrm{kg} \mathrm{BW}+$ Glipizide $2.5 \mathrm{mg} / \mathrm{kg} \mathrm{BW}$ ) was statistically significant with $\mathrm{P}$ value $=0.001$ using Anova test with post hoc tukey and scheffé, Bonferroni and Holm multiple comparison using SPSS software thus indicating that Aloe vera has definite glucose lowering effect.

\section{DISCUSSION}

Many drugs are prescribed concurrently in diabetes for glycemic control but still patients continue to have glycemic variability and higher blood sugar levels. Many people tend to self treat diabetes with commercially available herbal products and naturally growing plants of medicinal value like aloe vera, which has been studied in past. Many authors have found blood glucose lowering, hypolipidimic effect in Rats and Mice. ${ }^{8-10}$ Other authors found Aloe vera to be having wound healing activity and anti-psoriatic property. ${ }^{11-13}$ Using Pubmed and Google scholar as search engines, we found that there are many studies with ethanolic extract of Aloe vera but a few only with water soluble extract of Aloe vera. In our study, the results suggested that Aloe vera is having significant Blood glucose lowering potential better then Glipizide an insulin secretogogue. Similar results were observed by Naveen et al, but with ethanolic extract of aloe vera. ${ }^{14}$ The group receiving combination of Aloe vera and Glipizide has shown further better values of blood sugar lowering effect in rats suggesting the possibility of multiple mechanism of causing hypoglycaemia which was seen by P Naveen et al as well. ${ }^{14}$ As Alloxan treated diabetic Rats have low beta cells of Langerhans. In group 4 receiving Aloe vera and Glipizide concurrently, Glipizide administration the maximum beta cells stimulation would have occurred leaving behind little or no chance for aloe vera to stimulate Beta cells of Pancreas. But still the blood sugar lowering effect was better in group 4. This is probably because of additional property of Aloe vera by which aloe vera inhibits Alfa-Amylase in intestine. ${ }^{15}$ Also some authors have found increase in Bioavailability of few vitamins when co-administered with aloe vera. ${ }^{16}$ This may be one of the reason by which Aloe Vera would have increased the Bioavailability of Glipizide and hence the results in combination group were better. As in many other diseases inflammation is responsible for morbidity, similarly in diabetes as well, Inflammation has its role in pathogenesis of causing Hyperglycaemia. Authors have published many articles with the results suggestive of Anti-Inflammatory action of AloeVera. ${ }^{17}$ This can be one the effect by which Aloe vera by virtue of its anti inflammatory property reduces glucotoxicity in diabetes.

\section{CONCLUSION}

Water soluble extract of Aloe vera has significant hypoglycaemic property suggesting the possibility of Aloe vera to be a cheap alternative in diabetes. Further higher studies like Pharmacokinetic (PK) and Pharmacodynamic (PD) etc are required to postulate the Mechanism of Action of Aloe Vera in diabetes and to test real time effect of Aloe vera in Glucose and other metabolism.

\section{Funding: No funding sources}

Conflict of interest: None declared

Ethical approval: The study was approved by the Institutional Ethics Committee

\section{REFERENCES}

1. Available at: http://www.searo.who.int/india/mediacentre/events/2 016/en/ (Accessed by the Author on 15th June 2017).

2. Available at: www. nccih.nih.gov/health/aloevera (Accessed by the Author on 15th June 2017).

3. Zarvandi M, Rakhshandeh H, Abazari M, ShafieeNick R, Ghorbani A. Safety and efficacy of a polyherbal formulation for the management of dyslipidemia and hyperglycemia in patients with advanced-stage of type-2 diabetes. Biomed Pharmacother. 2017 May;89:69-75. 
4. Katsumata K, Katsumata Y, Ozawa T, Katsumata K, Jr. Potentiating effects of combined usage of three sulfonylurea drugs on the occurrence of alloxan diabetes in rats. Horm Metab Res. 1993;25:125-6.

5. OECD 2001- Guideline on Acute Oral Toxicity (AOT) Environmental health and safety monograph series on testing and adjustment No.425.

6. Rathor N, Arora T, Manocha S, Patil AN, Mediratta PK, Krishna K. Sharma Anticonvulsant activity of Aloe vera leaf extract in acute and chronic models of epilepsy in mice, Version of Record online: $20 \mathrm{NOV}$ 2013:477-485.

7. Cocchetto DM, Bjornsson TD. Methods for vascular access and collection of body fluids from the laboratory rat. J Pharm Sci. 1983;72(5):465-92.

8. Ajabnoor MA. Effect of aloes on blood glucose levels in normal and alloxan diabetic mice. $\mathbf{J}$ Ethnopharmacol. 1990;28:215-20.

9. Nejatzadeh-Barandozi F. Okyar A, Can A, Akev N, Baktir G, Sutlupinar S. Effect of Aloe vera leaves on blood glucose level in type I and type II diabetic rat models. Antibacterial activities and antioxidant capacity of Aloe vera. Phytother Res. 2001;3:157-61.

10. Kim K, Kim H, Kwon J, Lee S, Kong H, Im SA, et al. Hypoglycemic and hypolipidemic effects of processed Aloe vera gel in a mouse model of non-insulindependent diabetes mellitus. Phytomedicine. 2009;16(9):856-63.

11. Chithra P, Sajithlal GB, Chandrakasan G. Influence of Aloe vera on collagen characteristics in healing dermal wounds in rats. Mol. Cell. Biochem. 1998;181:71-6.

12. Rajendran A, Narayanan V, Gnanavel I. Study on the evaluation of therapeutic efficacy of Aloe vera sap in diabetes and treating wounds and inflammation in animals. J Appl. Sci. Res. 2007;3:1434-6.

13. Choonhakarn C, Busaracome P, Sripanidkulchai B, Sarakarn P. A prospective, randomized clinical trial comparing topical Aloe vera with $0.1 \%$ triamcinolone acetonide in mild to moderate plaque psoriasis. J. Eur. Acad. Dermatol. Venereol. 2010;24:168-72.

14. Naveen P, Padma J, Vasudha B, Gouda TS. HerbDrug Interaction between Ethanol Extract of Aloe Vera with Glipizide in Streptomycin Induced Diabetic Rats. Indo American Journal of Pharmaceutical Research. 2016:6(01).

15. Sudha P, Zinjarde SS, Bhargava SY, Kumar AR. Potent $\alpha$-amylase inhibitory activity of Indian Ayurvedic medicinal plants BMC Complement Altern Med. 2011;11:5-14.

16. Yun JM, Singh S, Jialal R, Rockwood J, Jialal I, Devaraj S. A randomized placebo-controlled crossover trial of aloe vera on bioavailability of Vitamins C and B 12, blood glucose, and lipid profile in healthy human subjects. Journal of Dietary Supplements. 2010;7(2):145-53.

17. Hutter JA, Salman M, Stavinova WB, Satsangi N, Williams RF, Streeper RT, et al. Anti-inflammatory CGlucosyl chromone from Aloe barbadensis J Nat Prod. 1996;59(5):541-3.

Cite this article as: Tiwari V, Gudsurkar G.

Assessment of oral hypoglycaemic activity of water soluble extract of aloe vera and its interaction with glipizide in alloxan induced diabetic Wistar Rats. Int J Basic Clin Pharmacol 2017;6:1917-20. 